\title{
Scarab beetles at the interface of wheel invention in nature and culture?
}

\author{
Gerhard Scholtz \\ Humboldt-Universität zu Berlin, Institut für Biologie/Vergleichende Zoologie, Philippstr. 13, 10115 Berlin, \\ Germany,gerhard.scholtz@rz.hu-berlin.de
}

Key words: Arthropoda, domestication, rolling, Scarabidae, Vertebrata

\begin{abstract}
In this review some examples of rolling behaviour in nature are described and discussed in terms of the realised degree of wheel-like locomotion. The combination of rotation and the use of the low friction resistance of circular and smooth surfaces to transport a heavy load, as is seen in scarab beetles rolling dung pills, is the closest degree of similarity to a wheel found in nature. Populations of dung rolling scarabs may have benefited from the early domestication of large mammals in the Middle East. I suggest that an increased opportunity to observe pill rolling scarab beetles has inspired humans to invent the wheel.
\end{abstract}

\section{Contents}

Introduction: observing nature …......................................... 139

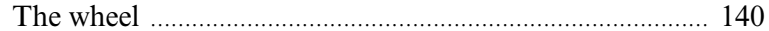

'Wheels' in nature ……………………………………......... 140

Scarab beetle wheels ......................................................... 143

Origins of wheels in human culture ……………............... 144

Scarabs, humans and cults ............................................. 144

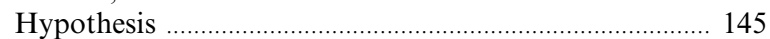

The exception that proves the rule …………………….... 146

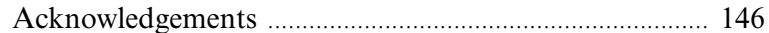

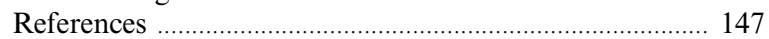

\section{Introduction: observing nature}

From very early on, humans have observed living nature. Even the oldest cultural documents, such as wall paintings in caves and other early artefacts, show that humans did this with a meticulous view for many anatomical and behavioural details (e.g., Eggebrecht, 1982; Schulz, 2007). So it may not come as a surprise that human thought is greatly influenced by perception (and misperception) of nature and its patterns. This is true not only for mythology (e.g., Myer, 1894; Hogue, 1987; Cherry, 1993; Mayor, 2000), but also for conceptual thought in science and the arts (Bredekamp, 2000, 2005). Also, technical innovation is sometimes the product of the observation of nature, i.e., humans copy and transform technical aspects derived from the living natural world into their cultural domain. We would probably not use airplanes, had there not been the observation of flying animals like birds, bats, or insects and the desire to achieve the same freedom from ground and gravity. This is reflected in the often bird-like design of early airplanes (Fig. 1). That the adoption of technical innovation from nature is not a new idea has nicely been documented by the Chinese tale on the invention of paper. According to this legend, the inventor of paper, Ts'ai Lun (89-106), got the idea from the observation of wasps forming paper nests by chewing tree bark and mixing it with saliva (Hogue, 1987). The same observation inspired the French entomologist de Réaumur (1683-1757) in 1719 to publish his idea about the use of wood for paper production (http://de.wikipedia.org/wiki/Papier- October 2008).

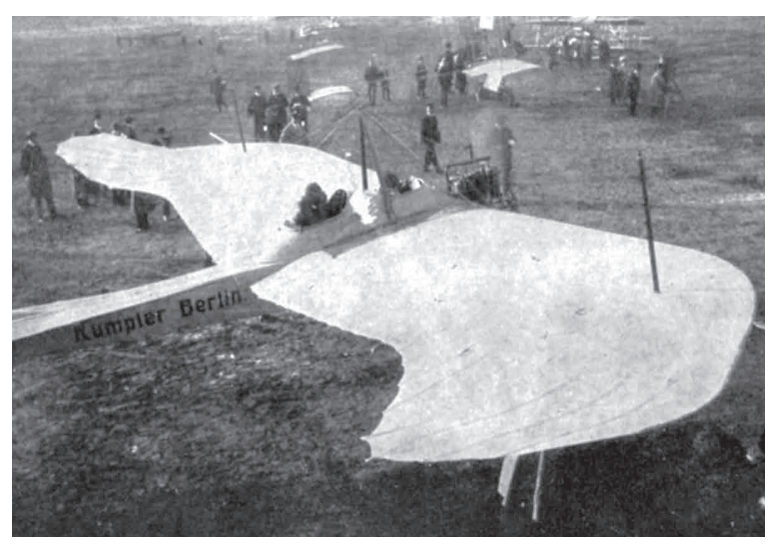

Fig. 1. An example of a technical object that is designed after a natural counterpart. The famous Rumpler 'Taube' (dove), an airplane from the 1910s. 


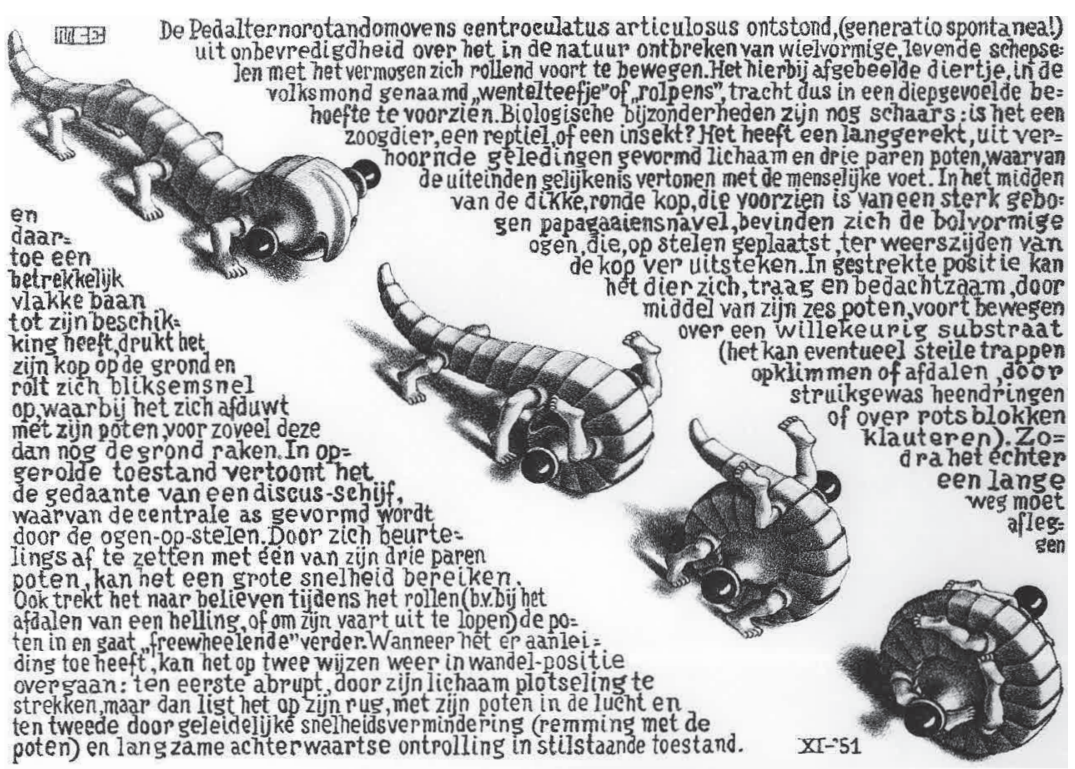

Fig. 2. Escher's artificial wheel-like animal 'Wentelteefje' (Curl-up), Pedalternorotandomovens centroculatus articulosus. The sequence from walking to wheel-like locomotion is shown from left to right.

M.C. Escher 'Curl-Up' (C) 2008 The M.C. Escher Company - Holland. All rights reserved. www.mcescher.com

\section{The wheel}

However, not all technical inventions are naturebased in the sense of ideas directly adopted from observed wildlife, and hence the human originality for these kinds of inventions is perceived to be of even higher value. One of the most important examples for a seemingly nature-independent cultural achievement is usually considered the invention of the wheel (e.g., Bronowski, 1976; Weiß, 2007). It is almost trivial to stress the importance of wheels and, more generally, the circular movement around an axis for our technical world and modern human culture. Wheels are virtually everywhere and if - in a thought experiment - every wheel and wheel-like function would suddenly disappear, all modern societies, even those only modestly technical, would collapse immediately. The universal high esteem for wheels is embedded in a long history of human fascination by round and circular objects and processes (see Bronowski, 1976; Jaffé, 1982; Wullen and Ebert, 2006). One only has to think of the admiration for the sun or the moon in many cultures, the circular appearance of seasons leading to round calendars, the circle and bowl as perfect geometrical shapes etc. Accordingly, the invention of the wheel is considered as one of the most important cultural achievements.
There are numerous essays and accounts from different perspectives, all dealing with the question of why the evolution of plants or animals did not lead to wheel-like structures, or to what extent the basic principles of rotation are realised by organisms (e.g., Gould, 1981; Walker, 1991; Meyer and Halbeisen, 2006). Some of these treatments approach the problem by wondering why nature did not make use of such an obvious thing as a wheel and even artists show concern. In 1951 the Dutch artist M.C. Escher invented and displayed the imaginary animal Wentelteefje ("Curl-up"), Pedalternorotandomovens centroculatus articulosus, in two lithographs as a result of his 'dissatisfaction concerning nature's lack of any wheel-shaped living creatures endowed with the power of propulsion by means of rolling themselves up' (Escher, 1967) (Fig. 2). These artificial animals have a worm-like body shape and normally walk on six feet. Only under certain circumstances do they curl up and form a perfect round structure that is able to roll.

\section{'Wheels' in nature}

Escher was simultaneously wrong and amazingly right in a prophetical way. He was wrong, because

\footnotetext{
${ }^{1}$ The Dutch word 'wentelteefje' refers to French toast.
} 
Fig. 3. The natural wheel-like animal Nannosquilla decemspinosa Rathbun, 1910, a stomatopod crustacean. Top: a photograph of a curled-up specimen with the pleon at the top and the cephalothorax at the bottom. The telson (right) touches the anterior head. Bottom: the sequence of the rolling behaviour (from left to right) showing the propulsion movement and rolling. The figure at the right side shows the posture used by the animal during wheel-like locomotion (see also photograph) (modified after Caldwell, 1979, adapted by permission from Macmillan Publishers Ltd: Nature, (C) 1979).

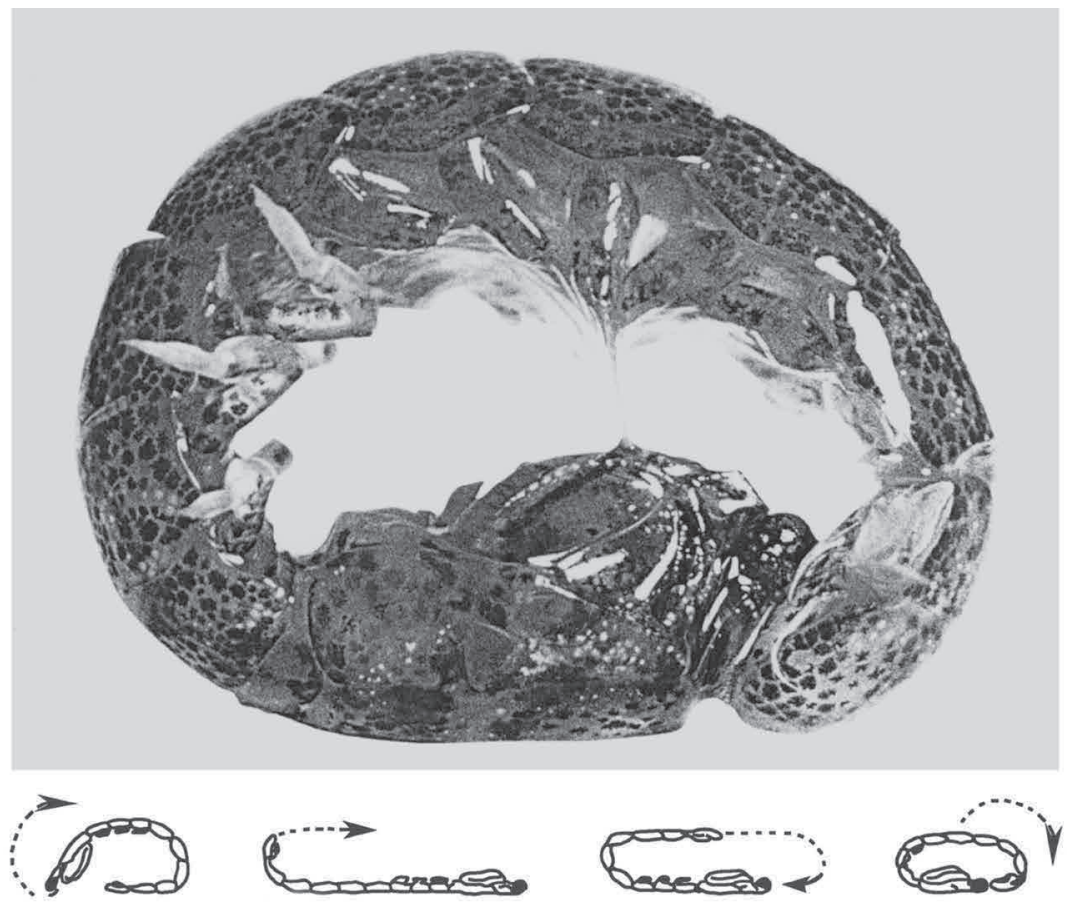

several instances of wheel-like organisms or parts of organisms have subsequently been detected and discussed. He was right, because two of these natural examples correspond to an amazing degree to his fantasy-born animal. As the 'Curl-up' these real animals are segmented worm-shaped creatures that normally walk but, under certain conditions, form a wheel and start rolling. One of these is the stomatopod crustacean Nannosquilla decemspinosa Rathbun, 1910, which lives at the Pacific coast of Panama. If a wave washes it onto the sand beach, it rolls back to the water by means of backward somersaults and consecutive rolling by forming a wheel with its entire body (Caldwell, 1979; Full et al., 1993) (Fig. 3). The other example is the mother-ofpearl caterpillar Pleuroptya ruralis Scopoli, 1763 that also rolls away backwards by adopting a wheel shape with its body when it is attacked (Brackenbury, 1997). The major difference between the two real and Escher's artificial animals is that the latter rolls forward whereas the caterpillar and the stomatopod roll backward with the tip of the tail ahead (Fig. 3). The prophetic view of the artist is nonetheless amazing.

One can add some more examples, such as the salamander Hydromantes platycephalus (Camp, 1916), or pangolins which curl themselves up and which have been observed to either passively or ac- tively role away from predators (Tenaza, 1975; García-París and Deban, 1995). Enrolment is a widespread phenomenon and seen, for instance, in animals such as hedgehogs, armadillos, lizards (e.g., Cordylus cataphractus Boie 1828), amphibians (e.g., Taricha granulosa (Skilton, 1849), Echinotriton chinhaiensis (Chang, 1932) (see Brodie et al., 1984; Johnson and Brodie, 1975), isopods, myriapods, and even fossil trilobites (Fig. 4). The latter are the oldest examples so far, since enrolled trilobites have already been reported from the Cambrian (Bergström, 1973). This curl-up behaviour is primarily used for protection against a predator, but might also include an intended or unintended passive rolling if there is a slope.

Other animals and plants use their round or cylindrical body for passive rolling. The tumble weed, Corispermum hyssopifolium Linnaeus, 1753, which is well known to most of us from classical Western movies, falls into this category. This herb grows into a rounded form that becomes disconnected from the grounded roots and spreads its seeds via a rolling motion caused by the wind. Another prominent example is the spider Carparachne aureoflava Lawrence, 1966 from the Namibian desert that can form a wheel by pulling in its legs and passively rolling down slopes (Henschel, 1990). The anomalan mole crab Hippa pacifica (Dana, 1852), which lives in the intertidal of 
sandy beaches in the tropics, shows a complex behaviour that helps this animal cope with the forces and turbulences of the breaking waves (Lastra et al., 2002). This behaviour includes lateral rolling of this almost cylindrically shaped animal moving down the slope of the beaches with the outgoing waves (own observation and pers. comm., M. Lastra, 2007). In all these cases, the whole animal or plant part undergoes the rolling movement and, accordingly, the similarity to a wheel on a cart is only given in part.

These examples of passively and actively rolling entire animals and plants lead to the problem of why wheels were not invented by nature as organs, e.g., an insect with six wheels instead of six legs. In fact, at the ultrastructural level a wheel-like organ is realised. It is found in the rotation of bacterial flagella showing a biochemical rotating motor at the flagella bases (Berg, 2003). However, bacteria do not roll on wheels in the strict sense. Furthermore, in the macroscopic biological world an organ with the shape or function of a wheel is not realised, not even similar to bacterial flagella.

There are two main reasons suggested for this. One is an external constraint specifying that under most natural conditions wheels are not advantageous (Gould, 1981; Walker, 1991; Meyer and Halbeisen, 2006) and indeed, everyone who ever left the smooth surface of streets and got stuck in mud or sand with a wheeled car or bike has experienced that this is a serious problem. However, this argument is only partially correct, because there are of course habitats where the ground is relatively smooth and hard and where the low friction resistance of a round surface might be advantageous (as is shown in the examples above).

The second line of reasoning is based on internal constraints (Gould, 1981; Meyer and Halbeisen,
2006). According to this view, wheels need a certain functional autonomy because they have to freely rotate around an axis. Organs, however, grow and must be innervated and supplied with nutrients, oxygen etc. Hence, an organ cannot function as a wheel (Gould, 1981; Meyer and Halbeisen, 2006). Again, this view seems too restricted. One could imagine a secretion product, or dead cellular material such as hair or horn, that is produced and centred around an organic structure formed during development as a ring, and then some glands that secrete a lubricant. That this example is not too far fetched is exemplified by the mucous product of the clitellum of annelids such as earth worms, which is formed as a ring around the body and which loses contact with the region that produces it (Peters and Walldorf, 1986). Of course, wheels of that kind are just good for passive rolling, but one can think of indirect propulsion with other body structures such as tails. Nevertheless, it is a matter of fact that a true wheel as an organ is not present in nature.

However, do other kinds of wheels occur in nature? What we consider a wheel depends on the wheel's definition, consciously or unconsciously used. If we define a wheel in the strict sense of Meyer and Halbeisen (2006), who state that a wheel is defined as a 'round object rotating around a fixed axis', then wheels are not realised in nature indeed. However, if we allow a more general definition by considering that the important element of wheel function is the use of the low friction resistance of round structures to carry a weight along a distance, then we $d o$ find wheels in nature. Perhaps we have to think along different lines, not so much about wheel organs but about wheel instruments or tools, or in other words, wheels produced and rolled by animals.
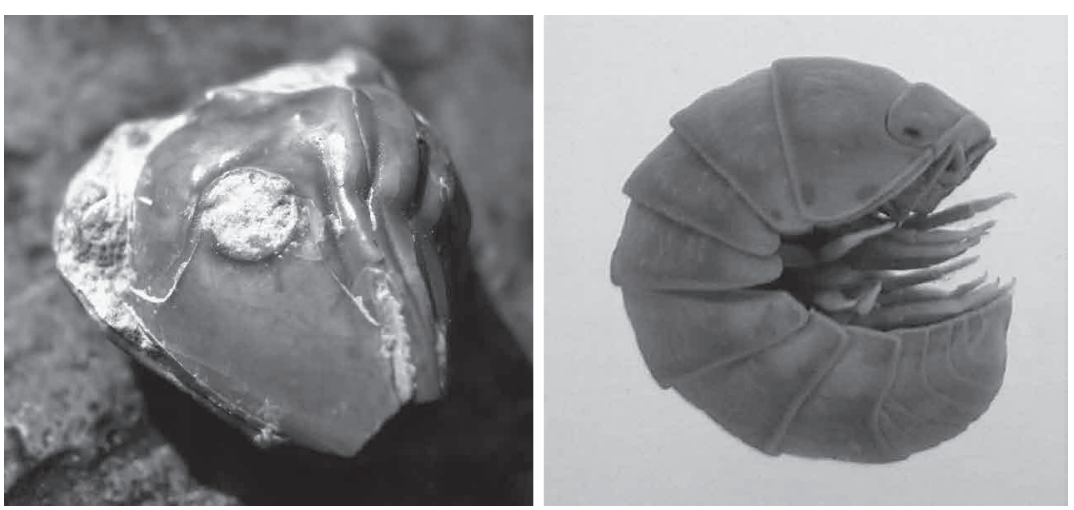

Fig. 4. More than 500 million years of enrolled arthropods. Left: An Ordovician trilobite (Asaphus raniceps Dalman, 1827). Right: A terrestrial isopod (Armadillo officinalis Dumeril, 1816). 
One such example is the perfectly round sand pellets produced by the mouthparts of the Australian sand bubbler crab Scopimera inflata A. Milne Edwards, 1873 (Fielder, 1970). These balls are the remains of feeding small organic particles in the sand of subtropical and tropical beaches. Between two high tides the beaches are virtually crowded by these pellets producing attractive patterns. Crabs of the genus Scopimera do not roll these sand balls at greater distances but after its formation each pellet is pushed backwards with the chelae through the legs to deposit it behind the animal (Fielder, 1970). However, the round shape of the crab's sand pellets is just a side effect of the rotated formation by the mouthparts and it eases the transport of the pellets only secondarily.

\section{Scarab beetle wheels}

Another more unambiguous instance of wheel use in the organic world before the advent of humans can be found among scarab beetles. More precisely, this concerns those species that form dung balls and roll them around (Fig. 5). This rolling activity is one of the most amazing actions in the animal world and forms a combination of various techniques and a distinct art of craftsmanship and engineering. Most of this behaviour has been known since ancient Egyptian times and has been described by ancient authors such as Aristophanes, Plinius Secundus, Plutarch, and Horapollo (Levinson and Levinson, 2001).
More recently, beautiful and detailed descriptions have been provided by the French entomologist Jean Henry Fabre (reprint in translation, 1977). For detail I refer the reader to Fabre's account and here I only wish to stress the parts related to the wheel aspect.

Dung beetles are attracted by the odour of fresh dung produced mainly by ungulates. They cut out pieces of dung and form a near-perfect bowl with a smooth surface by using their appendages and head structures. They then roll this bowl around to store it in excavated burrows as food for themselves or their offspring. By rolling the ball, they cover distances up to several meters while passing little elevations and valleys on their way. Mostly they push the rolling dung pills with a backwards walk, using their hind legs alternatively. The tips of the hindlegs form an axis that is parallel to the central axis around which the ball rotates. The combination of rotation around an axis, making use of the low friction resistance of circular and smooth surfaces to transport a heavy load, shows the closest degree of similarity to a wheel that I can think of. Interestingly, recent phylogenetic analyses of the dung beetles Scarabaeidae suggested that the dung rolling behaviour has evolved independently several times (Philips et al., 2004). Moreover, there is evidence that dung rolling was adaptively lost in several lineages of the Scarabaeini (Forgie et al., 2005). This provides an interesting parallel to the Middle East cultures in which the wheel was 'forgotten' and replaced by the use of domestic camels for several hundred years (see Bulliet, 1975).

Fig. 5. A scarab beetle (Scarabaeus semipunctatus Fabricius, 1792) rolling a dung pill.

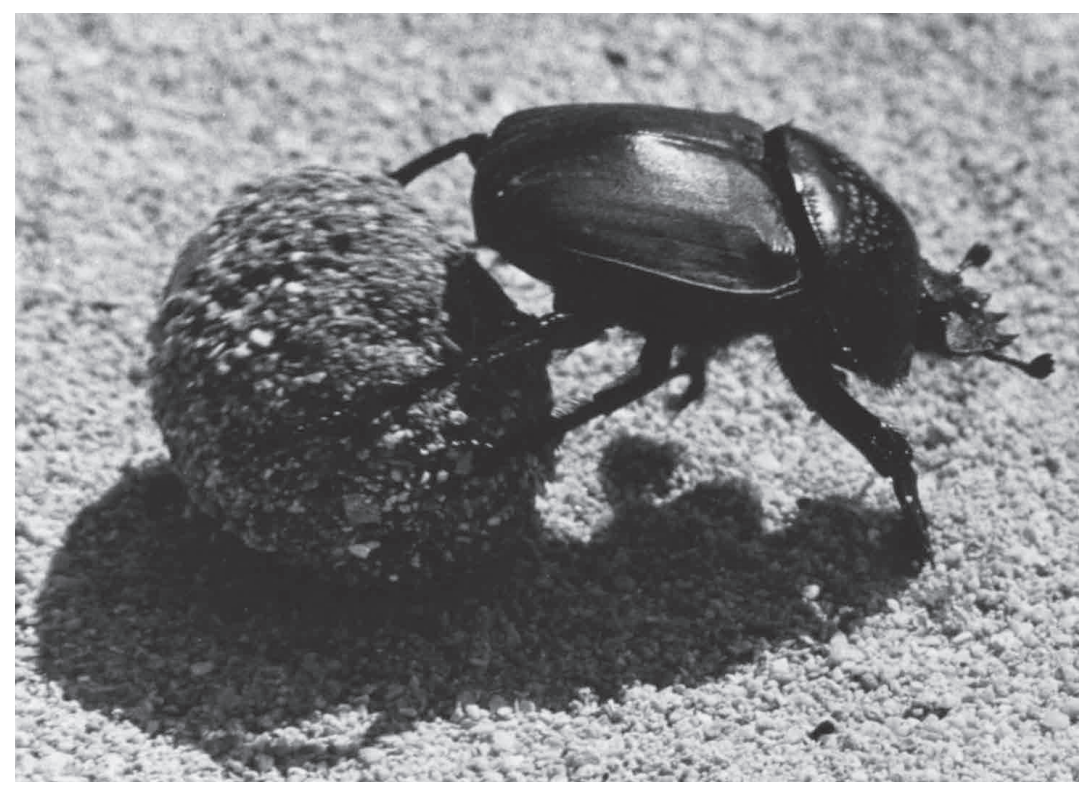




\section{Origins of wheels in human culture}

The general view archaeologists held for several decades was that the wheel was invented in the Middle East by the Sumerians around 3500 BC (see Burmeister, 2004). This hypothesis is based on i) pictograms showing a lateral view of sledge-like structures with a pair of discs underneath and ii) slightly younger records documenting the rapid improvement of wheel technology (Crouwel, 2004). The view of a Mesopotamian origin of the wheel has been challenged by more recent findings of wooden wheel discs, carts, and other indications for the use of wheels in Europe and the northern Caucasus region dating back to the same period (e.g., Schlichtherle, 2004; Trifonov, 2004). Accordingly, two competing hypothesis are put forward. The first hypothesis suggests a unique origin of the wheel which either adheres to the traditional view of a Middle East invention of wheel and cart including a cultural spread towards the north-west (Burmeister 2004, Sheratt 2004), or a different centre of origin (e.g., Maran, 2004). The alternative polycentric view claims that it is likely that the wheel was invented several times independently and in several areas, whenever allowed by the prevailing natural and cultural conditions (e.g., Häusler, 1996; Vosteen, 2002). The kind of argument in this controversy reminds me of disputes in biology about homology versus convergence of morphological characters (Scholtz, 2005). Furthermore, this question can be addressed with a 'complexity test' similar to that used in morphological comparisons (Scholtz 2005).

According to this, four arguments speak in favour of a monocentric origin of wheels in the area of the Middle East. The first argument concerns the natural conditions and properties of the landscape, the second concerns the occurrence of large domestic animals used as draught animals, a third argument is the similarity of wheel constructions, and the fourth is the fact that all new developments in wheel construction (tripartite disc wheels, strutted wheels, spoke wheels) were first documented in the Middle East and only subsequently in Europe and other areas (see e.g., Burmeister, 2004; Crouwel, 2004; Schlichtherle, 2004). Irrespective of the different views on the origin of wheels, it is beyond doubt that the Middle East is an area where the natural (Renger, 2004) and cultural conditions (Bernbeck, 2004), including the presence of large domestic animals (Benecke, 2004; Edwards et al., 2007) allowed an invention of this kind with its far reaching implications.

However, the situation might be even more complex; it has been suggested that perhaps the wheel in connection with a cart was only the last step, preceded or accompanied by use of the principle of circular movement in spindle whorls and potter's wheels (Burmeister, 2004). I want to add that also games with marbles and balls might be seen as precursors of wheels. Marbles are reported from the ancient Middle East (Holler, 1986). However, there is some evidence that these different achievements are not necessarily causally connected (see below).

\section{Scarabs, humans and cults}

The Scarabaeidae contains several large species in the Middle East including Scarabaeus pius Illiger, 1803, Kheper aegyptorium Latreille, 1827, Scarabaeus multidentatum Klug, 1845, and Gymnopleurus geoffroyi Fuessly, 1775 that produce dung balls or pills. Scarab beetles show intense competition for fresh dung heaps of large ruminants that are a rare commodity. The formation of a dung pill and the rolling behaviour may alleviate competition for nesting sites and food at the dung sources (Philips et $a l ., 2004)$. It is likely that the population size of scarab beetles increased in parallel with the growing number of domestic animals such as cows, sheep, and goats that were already kept during the transition from a nomadic life style to early settling and the onset of agriculture (Herre and Röhrs, 1990; Benecke, 2004).

The centre of domestication of cattle is thought to be the Middle East and to have started at c 8000 years BC (Edwards et al., 2007) and sheep and goats were part of this (Herre and Röhrs, 1999). Since domestic animals live in their close proximity, it was almost impossible for their owners to overlook the curious activities of dung beetles. Ancient people in the Middle East recognised and observed insects in great detail. One piece of evidence is provided by the Sumerian list (9th century BC, but presumably based on much older documents). This 'oldest book on zoology' (Harpaz, 1973: 27-28) includes 121 insect names that describe properties of the respective species (Harpaz, 1973). Thus, we can conclude that the people in ancient cultures in this area observed scarab beetles and were impressed by their complex and peculiar behaviours in one way or another. That 
this was indeed the case is demonstrated by the ancient Egyptian culture, which is famous for attributing a sacral meaning to scarab beetles. This sacral meaning has its roots in the detailed observations of the behaviour of dung beetles, although some misinterpretations occurred, such as the assumption of autogenesis, or that males alone produce the next generation (Weiss, 1927; Levinson and Levinson, 2001).

The sources and origins of the Egyptian scarabaeid cult remain obscure, but will have existed before it showed up in the historical record. Myer (1894) and Minas-Nerpel (2006) mention the first signs of scarab worship dating back to predynastic times (before $3000 \mathrm{BC}$ ), as indicated by buried beetles and containers in scarab design. The exact ritual meaning of these grave goods is unclear, however (Minas-Nerpel; 2006). In contrast to this, the oldest written records of scarabaeids found in pyramid texts at the end of the Fifth Dynasty ( 2367 - 2347 BC) already document the existence of an elaborated cult (Minas-Nerpel, 2006). It is astonishing that a complex cult like this should have had such a sudden appearance. One explanation might be that part of the scarab cult was imported - perhaps from Mesopotamia? Archaeological studies from the Sinai indicate an influence of the eastern Middle East regions on early Egyptian development (Gutbrod, 1975; Zick, 2007) and refer in particular to the spread of domestic animals and plants (Diamond, 2007).

The meaning of scarab beetles to ancient Egyptians was manifold but centred on Khepera (Kheper, Khepri, Chepri, or $\mathrm{Chefre}^{2}$ ), the Creator and God of the Rising Sun and its ascent during the early day (Myer, 1894; Sajó, 1910; Harpaz, 1973; Wade, 1922; Weiss 1927; Levinson and Levinson, 2001; Minas-Nerpel, 2006). Accordingly, Khepri was often depicted as a scarab beetle or with a scarab beetle as his head, and scarabs were shown with the sun disc between their legs. Old texts describe the deity as the 'Evolver of the Evolutions' (Myer, 1894: 104). The verb 'kheper' usually translated 'to be,' 'to exist,' 'to become,' also has the meaning of 'to roll' or 'to revolve' (Myer, 1894). Hence, the association of scarab beetles with discs, rotation,

\footnotetext{
${ }^{2}$ It is tempting to suggest that the modern words 'chafer' (English) and 'Käfer' (German) for beetles are derived from the name of this Egyptian deity, but this seems not entirely sure (see Deutsches Wörterbuch von Jacob und Wilhelm Grimm, online: http://germazope.uni-trier.de/Projects/DWB/ October 2008).
}

migration, and movement is obvious, also with round objects such as the sun disc (Myer, 1894; Levinson and Levinson, 2001; Minas-Nerpel, 2006). The generally accepted interpretation is that these associations are based on the observation that the new generation of scarab beetles originates from the round pill underneath the earth. This is also seen in the resurrection of the sun in the morning from the underworld, which is in turn associated with the belief of life after death (Myer, 1894; Weiss, 1927; Levinson and Levinson, 2001; Minas-Nerpel, 2006). I would however, as a serious alternative, consider the principle of rolling a round structure as the main source of this association.

\section{Hypothesis}

The points stated above take me to the central hypothesis of this article, in which the two strands of the above discussion are combined, namely the biology of scarab beetles as a representation of the use of wheels in nature and the origin of wheels in human culture. I suggest that the scarab's use of wheels has inspired humans in the Middle East to invent the wheel in their own cultural world. The possibility of intensive observations on the behaviour of scarabaeid beetles that follow the domestication of hooved mammals in this region, might have triggered the idea of the wheel as a means to carry loads. Accordingly, the great mythological role of the Scarabaeus might, at least in part, result from the high esteem held of the wheel. The invention of the wheel was particularly important because it combines the mythological aspects of round objects with a practical use. Wheeled carts became status symbols (as they are today), which is evident from ancient documents and from the fact that wheels are frequently found in graves of sovereigns (Schlichtherle, 2004). The military use of the new invention, the war chariot, led to a new chapter in the history of ancient cultures (Watson, 2005). The invention and early use of wheeled carts is often seen as correlated with domestication of large hooved mammals, which can be used as draught animals (Benecke, 2004). I suggest that domestic animals played a twofold role in the detection of the wheel. First, their domestication led to an increase of the population density of scarab beetles and thus made them more easily accessible to detailed observations. Secondly, as animals that 
can be used to pull ploughs, carts and wagons they also facilitated the use of wheels.

That the association between the dung ball of scarabaeids and wheels might be not so far fetched is documented by the vision of Ezekiel in the Bible (Ezekiel 1: 1-28). In his vision the prophet Ezekiel describes four cherub angels that resemble scarab beetles in several aspects including the metallic appearance, four wings with two different pairs, spines at the anterior limb pair, cleft feet, the back and forth movement, and the carrying of a wheel that is round in every direction. The idea that cherubim might represent scarab beetles originated from the Hungarian zoologist Sajó (1910) and was refined by the American cultural entomologist Hogue (1983). The interesting aspect of this hypothesis is that the so-called Ezekiel's Wheel, which is often depicted as two wheels interlaced at right angles and carried by the cherubim, might be the transformed description of the dung pill. Thus, the association of a scarab dung ball with a wheel might not be a foreign thought of Middle Eastern ancient people. Although it has to be stressed that that in this case, wheels were already known. Ezekiel was a priest, and he lived in Babylon during the $6^{\text {th }}$ century BC. As Hogue (1983) points out, a priest of that time in Babylon and Israel must have been familiar with scarab cults and may been an observer of this animal's behaviour.

\section{The exception that proves the rule}

If the wheel is as important as we think towards the building up of civilisation; and if, following the assumption of the polycentric invention of wheels, a distinct degree of cultural development in combination with landscape and environmental conditions leads to technical innovations of certain kinds, why then was the wheel not invented and used in preColumbian American cultures? The complexity of the culture poses no problem, and the environmental conditions for the use of wheels were there even better than in Stone or Bronze Age Europe. Moreover, terracotta toys with wheels and spindle whorls were used, but surprisingly this knowledge led to neither potter's wheels, nor cart wheels (Burmeister, 2004; Diamond, 2007). This clearly shows the independence of these achievements. There is no necessity to derive cart or potter's wheels from spindle whorls or toys.
The first thing that came to my mind when I thought about this phenomenon was that perhaps there are no scarab beetles producing balls of dung in America. This is, however, not the case. In Mexico and other areas, there is a number of scarab species that form dung pills (Philips et al., 2004). Furthermore, the ancient Americans were well aware of the arthropod and insect world, as is clear from the catalogue of the great Aztec exhibition (Catalogue 2003) that documents numerous beautiful and sometimes detailed pictures and statues of centipedes, spiders, scorpions and many insects - including a scarab beetle, Canthon humectus Say, 1831 (MacGregor, 1969). Thus, if the observation of scarabs might have been contributed to the invention of the wheel, then why did the ancient American people not get the inspiration from the observation of these animals? One quite trivial answer is that nearly identical observations do not necessarily lead to the same or similar conclusions. More importantly, however, is the absence in Middle and South America of domesticized large hooved animals (see also Diamond, 2007). Consequently, dung beetles were only occasionally observed, and did not obtain the same level of attention compared to the situation in the ancient Middle East.

In conclusion I suggest that the invention of the wheel in human culture was merely a reinvention, copied from nature and from dung beetles in particular.

\section{Acknowledgements}

This essay was inspired by the preparations to the exhibition 'Der Ball ist rund - Kreis Kugel Kosmos' which was held at the Pergamonmuseum Berlin during the Football World Championship 2006 in Germany. I thank my family, the group Vergleichende Zoologie at the Humboldt-Universität zu Berlin, and Martina Minas-Nerpel for inspiring discussions and Frederick Schram and the reviewers of the journal for helpful comments on the manuscript. Thanks are due to Roy Caldwell who provided the photograph of Nannosquilla. Peter Lederer's photography of a scarab beetle is gratefully acknowledged. 


\section{References}

Berg HC. 2003. The rotary motor of bacterial flagella. Annual Reviews of Biochemistry 72: 19-54.

Benecke N. 2004. Die Domestikation der Zugtiere. In: Fansa M. and Burmeister S, eds. Rad und Wagen. Mainz: Verlag Philipp von Zabern, 455-466.

Bergström J. 1973. Organization, life, and systematics of trilobites. Fossils and Strata 2: 1-69.

Bernbeck R. 2004.Gesellschaft und Technologie im frühgeschichtlichen Mesopotamien. In: Fansa M. and Burmeister S, eds. Rad und Wagen. Mainz: Verlag Philipp von Zabern, 49-68.

Brackenbury J. 1997. Caterpillar kinematics. Nature 390: 453.

Bredekamp H. 2000. Antikensehnsucht und Maschinenglauben, Second edition. Berlin: Wagenbach.

Bredekamp H. 2005. Darwins Korallen. Berlin: Wagenbach.

Brodie Jr ED, Nussbaum RA, DiGiovanni M. 1984. Antipredator adaptations of Asian salamanders (Salamandridae). Herpetologica 40: 56-86.

Bronowski J. 1976. Der Aufstieg des Menschen. Frankfurt: Ullstein.

Bulliet RH. 1975. The Camel and the Wheel. Cambridge: Harvard University Press.

Burmeister, S. 2004. Der Wagen im Neolithikum und in der Bronzezeit: Erfindung, Ausbreitung und Funktion der ersten Fahrzeuge. In: Fansa, M. and Burmeister, S. eds. Rad und Wagen. Mainz: Verlag Philipp von Zabern, 13-40.

Caldwell RL. 1979. A unique form of locomotion in a stomatopod - backward somersaulting. Nature 282: 71-73.

Catalogue 2003. Azteken. Köln: DuMont.

Cherry RH. 1993. Insects in the mythology of Native Americans. American Entomologist 39: 16-21.

Crouwel J. 2004. Der Alte Orient und seine Rolle in Entwicklung von Fahrzeugen. In: Fansa M. and Burmeister S, eds. Rad und Wagen. Mainz: Verlag Philipp von Zabern, 69-86.

Diamond J. 2007. Arm und Reich, Thirdedition. Frankfurt/ Main: Fischer Taschenbuch Verlag.

Edwards CJ, Bollongino R, Scheu A, et al. 2007. Mitochondrial DNA analysis shows Near Eastern Neolithic origin for domestic cattle and no indication of domestication of European aurochs. Proceedings of the Royal Society, London B 274: 1377-1385.

Eggebrecht A. 1982. Die Darstellungen. In: Lascaux - Höhle der Eiszeit. Mainz: Verlag Philipp von Zabern, 30-59.

Escher MC. 1967. The Graphic Work of M.C. Escher. New York: Ballantine Books.

Fabre J-H. 1977. Das offenbare Geheimnis. Frankfurt: Insel Verlag.

Fielder DR. 1970. The feeding behaviour of the sand crab Scopimera inflata (Decapoda, Ocypodidae) Journal of $\mathrm{Zo}$ ology, London 160: 35-49.

Forgie SA, Philips TK, Scholtz CH. 2005. Evolution of the Scarabaeini (Scarabaeidae: Scarabaeinae). Systematic Entomology 30: 60-96.

Full R, Earis K, Wong M, Caldwell R. 1993. Locomotion like a wheel? Nature 365: 495.

García-París M, Deban SM. 1995. A novel antipredator mechanism in salamanders: rolling escape in Hydromantes platycephalus. Journal of Herpetology 29: 149-151.
Gould SJ. 1981. Kingdoms without wheels. Natural History 90: 42-48.

Gutbrod K. 1975. DuMont's Geschichte der frühen Kulturen der Welt. Köln: DuMont Schauberg.

Häusler A. 1996. Transportmittel und Wegenetz. In: Preuß J, ed. Das Neolithikum in Mitteleuropa, Teil A., Weißbach: Beier und Beran, 167-176.

Harpaz I. 1973. Early entomology in the Middle East. In: Smith RF, Mittler TE and Smith CN eds. History of Entomology. El Camino Way: Annual Reviews Inc., 21-36.

Henschel JR. 1990. Spiders wheel to escape. South African Journal of Science 86: 151-152.

Herre W, Röhrs M. 1990. Haustiere - zoologisch gesehen. Stuttgart: Fischer Verlag.

Hogue CL. 1983. An entomological explanation of Ezekiel's wheels? Entomological News 94: 73-80.

Hogue CL. 1987. Cultural entomology. Annual Reviews of Entomology 32: 181-199.

Holler R. 1986. Murmeln. München: Hugendubel.

Jaffé A. 1982. Bildende Kunst als Symbol. In: Jung CG, von Franz M-L, eds. Der Mensch und seine Symbole. Olten: Walter-Verlag, 232-271.

Johnson JA, Brodie ED. 1975. The selective advantage of the defensive posture of the newt, Taricha granulosa. American Midland Naturalist 93: 139-148.

Lastra M, Dugan JE, Hubbard DM. 2002. Burrowing and swash behavior of the Pacific mole crab Hippa pacifica (Anomura, Hippidae) in tropical sandy beaches. Journal of Crustacean Biology 22: 53-58.

Levinson H, Levinson A. 2001. Venerated beetles and their cultural-historical background in ancient Egypt. Spixiana, Supplement 27: 33-75.

MacGregor R. 1969. La représentation des insectes dans l'ancien Mexique. L'Entomologiste 25: 1-8.

Maran J. 2004. Kulturkontakte und Wege der Ausbreitung der Wagentechnologie im 4. Jahrtausend v. Chr. In: Fansa M. and Burmeister S, eds. Rad und Wagen. Mainz: Verlag Philipp von Zabern, 429-442.

Mayor A. 2000. The First Fossil Hunters. Princeton: Princeton University Press.

Meyer VR, Halbeisen M. 2006. Warum gibt es in der Natur keine Räder? Biologie in Unserer Zeit 36: 120-123.

Minas-Nerpel M. 2006. Der Gott Chepri: Untersuchungen zu Schriftzeugnissen und ikonographischen Quellen vom Alten Reich bis in griechisch-römische Zeit. Leuven: Peeters.

Myer I. 1894. Scarabs. Leipzig: Harrassowitz.

Peters W, Walldorf V. 1986. Der Regenwurm - Lumbricus terrestris L.: eine Praktikumsanleitung. Heidelberg: Quelle and Meyer.

Philips TK, Pretorius E, Scholtz CH. 2004. A phylogenetic analysis of dung beetles (Scarabaeinae: Scarabaeidae): unrolling an evolutionary history. Invertebrate Systematics 18: $53-88$

Renger J. 2004. Die naturräumlichen Bedingungen im Alten Orient im 4. und frühen 3. Jt. v. Chr. In: Fansa M. and Burmeister S, eds. Rad und Wagen. Mainz: Verlag Philipp von Zabern, 41-48.

Sajó K. 1910. Aus dem Leben der Käfer. Leipzig: Thomas.

Schlichtherle, H. 2004. Wagenfunde aus den Seeufersiedlungen im zirkumalpinen Raum. In: Fansa M. and Burmeister S, eds. Rad und Wagen. Mainz: Verlag Philipp von Zabern, 295-314. 
Scholtz G. 2005. Homology and ontogeny: Pattern and process in comparative developmental biology. Theory in Biosciences 124: 121-143.

Schulz M. 2007. Das magische Mammut. Der Spiegel, 27 02.07.2007, 134-145.

Sherratt A. 2004. Wagen, Pflug, Rind: ihre Ausbreitung und Nutzung - Probleme der Quelleninterpretation. In: Fansa M. and Burmeister S, eds. Rad und Wagen. Mainz: Verlag Philipp von Zabern, 409-428.

Tenaza RR. 1975. Pangolins rolling away from predation risks. Journal of Mammalogy 56: 257.

Trifonov V. 2004. Die Majkop-Kultur und die ersten Wagen in der südrussischen Steppe. In: Fansa M. and Burmeister S, eds. Rad und Wagen. Mainz: Verlag Philipp von Zabern, 167-176.

Vosteen MU. 2002. Die fünffache Erfindung von Rad und Wagen. In: Köninger J, Mainberg, M, Schlichtherle H, Vosteen MU, eds. Schleife, Schlitten, Rad und Wagen. Zur Frage früher Transportmittel nördlich der Alpen. Freiburg: Hemmenhofer Scripte 3, Landesdenkmalamt BadenWürttemberg, 143-148.
Wade JS. 1922. The scarab: emblem of eternity. Canadian Entomologist 54: 145-149.

Walker I. 1991. Why legs and not wheels? Acta Biotheoretica 39: $151-155$.

Watson P. 2005. Ideas. A History from Fire to Freud. London: Weidenfeld and Nicolson.

Weiß B. 2007. Als die Welt ins Rollen kam. GeoKompakt 13: 104-108.

Weiss HB. 1927. The Scarabaeus of the ancient Egyptians. American Naturalist 61: 353-369.

Wullen M, Ebert B. eds. 2006. Der Ball ist rund-Kreis Kugel Kosmos. Berlin: Staatliche Museen zu Berlin.

Zick M. 2007. Prähistorisches Fort Knox. Der Tagesspiegel, Nr. 19529, 26.4.2007: 32

Received: 8 July 2008

Accepted: 29 September 2008

Published online: 3 November 2008 